\title{
Polluted water, stinking water, frozen water, no water: A life threatening situation! Perspectives from Exodus 1-11 and 15-17
}

\author{
Van der Walt, Steven \\ University of the Free State \\ ideo@caw.ac.za
}

\begin{abstract}
The article highlights the life threatening consequences Israel could have faced if they did not stay within the creational rhythm which YHWH planned for them. Natural phenomena, in which water played a significant role, contributed to these life threatening circumstances. Certain pericopes of two external narratives (Ex 1-14; Ex 15-18) form the backbone of this article. Natural phenomena (transformation of water) are being used to highlight the fact that YHWH alone is creator God: live according to His ordinances (rhythm) and be assure to be blessed; do not live accordingly, and be assure that the natural rhythm of nature could turn upside down with devastating consequences such as polluted water, stinking water, frozen water or, no water at all. It turns out that being without life-giving water is just as dangerous as being without YHWH, thus a life threatening situation.
\end{abstract}

\section{Introduction}

The viewpoint of this paper stems from the assumption that nature and its natural phenomena within, have but one author, YHWH. YHWH is creator, not only of the cosmos and the world, but of life (Fretheim 1991a:385-386). To be more specific, YHWH created life, but according to the Hebrew bible, also created for Himself a people. The aim of this paper is to indicate that there were important aspects with regard to the rhythm between YHWH's creation and his people, living life as His people. Moving beyond that rhythm had life threatening consequences, in which natural phenomena played a significant role.

1 This article was read as a paper at the OTWSA conference hosted by UNISA at Kwalata Lodge, Gauteng, on 2 September 2015. 
Deuteronomistic history gives ample examples of a disturbed rhythm which lead to life threatening circumstances. During Israel's time of exile (587 BC), Israel did what many people do in times of difficulty: became introspective. One way of being introspective is to ask questions: What went wrong? Or, what happened? Or, what is the reason for our being in this crisis situation? For Israel, the crisis of the Babylonian exile brought remembrance of things past - or in the words of some, 'Chronicles of memory' (Crites 1971:298). The memory of YHWH's creational power, great redemptive acts and promises comforted Israel in times of distress. It reminded them that their being there, in distress, had also been the result of a disturbed creational rhythm, in which they had to take blame upon themselves as well.

Fragments of two external narratives (as told by the narrator/s of the Deuteronomistic history) form the backbone of this paper. In the first narrative (Ex. 1-14) YHWH uses miraculous acts to create for Himself a people and to deliver them from bondage through His agent Moses. Natural phenomena are used to highlight the fact that YHWH alone is creator God: live according to His ordinances (rhythm) and be sure to be blessed; do not live accordingly, and be assured that the natural rhythm of nature could turn upside down with devastating consequences (polluted water, stinking water, frozen water), as was the case with regards to Egypt.

The second narrative (Ex 15-18) heralds the so called 'Wilderness tradition'. A water motif is being used to show Israel that the same God who turned nature 'upside down' in Egypt, is able to restore nature to its healthy origins. Israel is then being invited, but also warned to stay within the rhythmic boundaries which YHWH has set for them (Ex 15:26).

\section{Creation turned upside down}

\subsection{Pharaoh's mistake}

The narrative problem of Exodus is defined in Exodus 1. Pharaoh enslaved the Israelites and forced them to build his store cities (Ex 1:8-14; 5:1-23). In doing so, Israel glorified Pharaoh's reign, 'and not the reign of the God whose servants they are as descendants of Abraham' (Leder 2010:95). Pharaoh's act of enslavement (Ex 1:11) was also intentional. He tried to prevent the Israelites from multiplying. The 'future of YHWH's promises 
and of Israel's ancestors' was to be endangered 'by the oppressive power of Pharaoh', who feared the Hebrews and enslaved them (Birch et al 1999:105).

Gross (2010:115-118) writes in an article on Exodus 2 that, according to Jewish tradition, 'the men of Israel were so demoralized by Pharaoh's genocidal edict that they withdrew from physical intimacy with their wives, in order to avoid creating a pregnancy, the fruit of which would only be destined for death.' The righteous Israelite women on the other hand, 'solaced and reassured their husbands-by which affirmative act of faith they merited the redemption of their people' (Gross 2010:115-118). Therefore, '[...] the more they were oppressed, the more they multiplied and spread' (Ex 1:12). The plan of Pharaoh to prevent the Israelites from multiplying by enforcing slavery, did not work. Accordingly, Pharaoh made a new plan, to kill the Israelites' new-born baby boys (Ex 1:16, 22).

Fretheim (1991a:385-386) argues that the Pharaoh's oppressive measures against Israel are viewed as 'fundamentally anti-life and anti-creation' [...] 'They strike right at the point where the creational promise of fruitfulness is being fulfilled in Israel'. YHWH will thus not tolerate someone who threatens to go against his creational plans, as the Pharaoh did. YHWH is on the verge of creating a nation and the Pharaoh tries to intervene. Firstly, by enslaving them to hardship and then, by throwing Israel's newborn babies into the Nile River. (Ex 1:11-22). The problem in a nutshell: Israel was enslaved by Pharaoh. They were forced to build his store cities. Through this, Pharaoh, and not YHWH was glorified. Pharaoh went against YHWH's creational plan with Israel by first enslaving them and then killing their sons.

\subsection{Israel's cry}

Cry (murmuring) forms a bridge motif which links the narrative problem in Exodus 1 to the unfolding of the plot in the rest of the Exodus narrative and eventually, to the denouement of the plot in Exodus 14 and 15. ${ }^{2}$ The focus point of the murmuring motif, however, is not on Israel's complaints

2 Van der Walt (2014:146) points to the fact that the 'Israelite's thunderous cry is heard for the last time in the Exodus narrative' when their murmuring channelled through Moses and took the form of a complaint. Thus, the cry-motif started to transform into a murmuring-motif. Exodus 14:10 is therefore the start of many such murmurings which Israel would have voiced during their Wilderness sojourn. 
but, rather on YHWH as the One who hears and remembers: 'The fact that God hears means that God will act' (House 1998:91). There are four Hebrew words in Exodus 1-11 which suggest this conjecture:

\subsubsection{Bakah (Ex 2:6)}

In the context of Exodus 2:6 bakah is used to describe a baby 'crying in distress [...] thus the baby Moses began to cry in the Pharaoh's daughter's presence [Ex 2:6]' (TWOT 243). If Fretheim (1991b:7) is correct regarding the mirroring effect (of word-play) in the structural outline of Exodus 1-15, Moses' crying and Pharaoh's daughter's having compassion over him, mirror to the outcry of the people and YHWH hearing them (Ex 2:23). In the words of Childs (1965:116): 'The role of the princess climaxes the theme which runs throughout the story [...]. The real action still lies in the future. These events are only preparation' of things to come.

\subsubsection{Zaaq (Ex 2:23)}

The first appearance of the word zaaq in the Canon of Scriptures is in Exodus 2:23. The word indicates 'crying out for aid in time of emergency, especially for divine help (Strong 2001:445). In Exodus 2:25 the narrator says 'God looked on the Israelites and was concerned about them'. Literally it means that 'God looked on the Israelites and knew' (Waltke 2007:357). The narrator furthermore creates the anticipation of 'an exclusive relationship in which God pledges to treat the elect as his 'treasured possession" Waltke (2007:357).

\subsubsection{Tseaqah (Ex 3:7, 9)}

The original meaning of tseaqah in Arabic is 'sound as thunder', thus stressing the cry as 'to call out for help under great distress or to utter an exclamation in great excitement' or 'anguish'. As is the case in Exodus 2:23, the cry is not unnoticed. YHWH 'sees', YHWH 'hears', and YHWH is 'concerned' (Kaiser Jr. 1990:316; BDB 1947a ${ }^{4}$ ). Verse 9 repeats the fact that YHWH has heard and saw 'Israel's present need' and offers the solution: '[...] the formal commissioning of Moses as God's emissary to lead Israel out of Egypt' (Kaiser Jr. 1990:316).

3 YHWH hears Israel's cries and He remembers his own promises.

4 BibleWorks 2008 (electronic ed.) 


\subsubsection{Tsaaq (Ex 5:8)}

Tsaaq is synonym to zaaq [Ex 2:23] (Strong 2001:445, 770). ${ }^{5}$ In Exodus 2 and 3 YHWH heard the cry of the people. In Exodus 5 Pharaoh also hears the cry (via Moses); the difference however is that Pharaoh's solution to the cry is to let the people suffer more. The tension in the narrative therefore intensifies as there is not a quick solution to the people's cries. In fact, Fretheim (1991b:83) says that the cries are suddenly 'deafening silent' in Exodus 5. Everyone (Moses, Pharaoh, the slave drivers, Israelite foremen, YHWH) has a say, except the people. The cry-motif in Exodus 5 is therefore subtly hidden by the author, providing 'a picture of the depths of Israel's situation and the ruthlessness of oppressive systems' (Fretheim 1991b:83). The tension builds up and helps to set the stage for YHWH's redemptive plan further on in the narrative.

\subsection{YHWH's reply}

The above (murmuring) words which highlight Israel's distress, clearly point to the fact that YHWH sees, hears, and is concerned about his people's situation. He answers with a display of His creational power (signs and wonders) with nine wonders and one plague. ${ }^{6}$ The Hebrew words for signs and wonders are 'oth' and 'mophet'. 'Oth' and 'mophet' have a specific purpose, in that they always point to something in the future. The actual wonder which is described at a certain moment has therefore more to it than just the specific event (Van der Walt 2014:80). It could thus serve as a warning for something worse to come in future.

The scope of this paper does not allow an investigation into all of the nine wonders. The focus will thus be on water as motif. YHWH showed His creational power by means of transforming water into blood - and other wonders; or by using it as a medium to produce something extraordinary ${ }^{7}$

5 Strong 2001 (2199 - Ex. 2:23) and Strong 2001 (6817 - Ex. 5:8)

6 Traditionally many scholars speak of the 10 plagues. Van der Walt (2014:69-83) explains why he prefers to speak of nine wonders and one plague.

7 The parting of the sea narrative (Ex 14) also has a strong water motif, positive and negative. For Israel the crossing through the sea on dry ground points to a new beginning. For Egypt, the closing of the sea means death. For an extensive view on this narrative see Van der Walt (2014:85-89; 109-114). 
like a magnitude of frogs beyond measure; or by producing hail that demolished everything it touched.

In the Canon of Scriptures water serves as a strong motif pointing to important aspects regarding YHWH's creational power. To name but a few: new life/re-birth (Childs 2004:237; Propp 1998:562); new beginnings (Tolmie 1999:112; Houtman 1988:129); chaos (Fretheim1991a:396); life (Klopper 2005:255; Lemmelijn 2007:409); and purifying and healing (Propp1998:561). In at least three of the nine wonders described in Exodus 7-11, water as motif highlights YHWH's creational power when He reacts to Israel's cry and Pharaoh's mistake.

\subsubsection{Polluted water}

The nine wonders narrated in Exodus 7-11 are structured in three triads (Van der Walt 2014:68). The first triad's setting was the Nile River. YHWH commanded Moses to meet the Pharaoh on the banks of the Nile River in the morning. The purpose of Pharaoh's visit to the Nile was to worship the river, 'which was honoured by the Egyptians' as one of their supreme deities (Keil\&Delitzsch 2011a:310). For Egyptians, the Nile was the birthplace of Egypt. It was there, at the so called birth place of Egypt, that Moses declared the will of YHWH to Pharaoh to let Israel go. When Pharaoh refused, YHWH transformed Pharaoh's own (river) deity into blood, thus showing him (Pharaoh) that YHWH had power over his so-called (river) deity (Brueggemann 1997:505); and to Israel that He (YHWH) 'is indeed both present and powerful' (Durham 1987:96).

More important though: YHWH is the one who created the Nile. In this wonder (the first of nine), the Creator and Giver of the life-giving waters demonstrated his power to Pharaoh (Brueggemann 1997:505). What's more, YHWH showed his power over life and death (Ex 7:17) and so the life-giving waters of the Nile were transformed into a canal of death (Houtman 1989:34): 'The fish in the Nile died, and the river smelled so bad that the Egyptians could not drink its water' (Ex 7:21).

Not only was the water in the Nile affected, but every single drop of water was transformed: 'Blood was everywhere in Egypt' (Ex 7:10, 21). According to Fretheim (1991a:388) this phrase suggests two sign values of blood: 
The comprehensiveness of blood in the land shows that it is 'more than' a hyperbole. Fretheim (1991a:388) compares the image of blood with the 'oracle against Egypt in Ezekiel 32:6 [...], linking blood in land and water: 'I will drench the land with your flowing blood all the way to the mountains, and the ravines will be filled with your flesh." With this remark Fretheim explains that although the word blood (dawm) is not used in Exodus 14-15, 'the image is one of the sea becoming red with Egyptian blood'.

'The cry of the Egyptians is as extensive as the blood in this sign [...]' (Ex. 11:6). 'Blood, which will be a sign of deliverance for Israel (Ex 12:13), here becomes a sign of disaster for Egypt.' Fretheim comes to this conclusion because of the verb nakah (Ex 7:17 - smite) which 'points forward to its use in Exodus 12:12-13, 29).'

A final comment on the first wonder is the fact that the magicians duplicated the miracle. They did not duplicate the Nile River's transformation, for YHWH had already done that. It must have been other water sources. There is some humour in this though, as they could not reverse the act and therefore just worsened the scenario of making water undrinkable (Durham 1987:98; Ford 2006:132).

\subsubsection{Stinking water}

Childs (1974b:154-155) mentioned that commentators had 'long since sought' to connect the appearance of the frogs with the polluting of the Nile. The text itself however, makes no link between the polluting of the Nile and the appearance of the frogs. But, out of the stinking water came frogs and they were everywhere (Ex. 8:4): In the people's homes, in their bedrooms, their beds, their ovens and in the kneading bowls, even upon them.

The frogs were not dangerous, but they were extremely annoying and made so much noise that it was hard to withstand them (Ulmer 2009:61)! Lerner (2010:662-3) is of opinion that the reason why Moses 'cried out' to YHWH in Exodus 8:8 was that, because of the absolute loudness of the frogs, he could not hear himself pray. Lockyer then rightfully noticed two things about the wonder of the frogs: First of all 'it was a severe trial to the religious feelings of the Egyptians and tended to bring their religion into contempt'. Secondly, the 'Egyptians worshipped cleanliness and set much value upon it' (Lockyer 1961:50). 
One could imagine that with frogs everywhere ${ }^{8}$ even in beds and in ovens, it must have been disgusting to the Egyptians, not to mention the stink that filled the land after they died. Speaking of which: The Pharaoh's magicians copied the appearance of frogs and to some extent, it's even humorous ${ }^{9}$ (Propp 1998:349), because they added to the annoying effect of the frogs, but they couldn't make them perish all in one single moment, like YHWH did through His agent, Moses. Also the Pharaoh suffered from the annoying effect the frogs had and the stench of the dead frogs got to his nose too. The stench actually served as a warning and pointed ahead to something worse to come, namely the stench of death. The stench therefore probably pointed to the final plague, but also to the last blow: The fate of Egypt when the Pharaoh's men were buried in the waters of the sea of reeds.

\subsubsection{Frozen water}

The wonder of frozen water (hail) leads the way for the third triad. In relation to the previous wonders, it has one of the longest descriptions in the entire story. It 'marks the build-up within the narrative leading to the final judgment' (Childs 1974b:158), which is the plague of death. This final triad 'suggests that there will be some change in the encounters between YHWH and Pharaoh after this point. 'This time' (Ex. 9:14) refers to the final three wonders, and possibly to the slaying of the firstborn as well (Ford 2007:153).

The last three wonders are introduced with an extended speech of YHWH directed to Pharaoh. It is said to Pharaoh that by now, he and the whole of Egypt could have been wiped from the earth (Ex. 9:15), but for the following two reasons have been spared: To show Pharaoh YHWH's power and to declare His glory throughout the world.

With this wonder an alternative, differing from the previous wonders, is offered. A warning comes:

8 The Egyptians had a female deity with a frog's head, known as Heka or Heqt. She was worshiped as the wife of Chnum, god of cataracts or of inundation and she was a symbol of fertility and regeneration for the Egyptians (Wilkinson 2003:229. More-over she had power over the crocodiles, which were supposed to keep the frog population down. Ironically, with the frog wonder there was an inundation of frogs.

9 At this point it begins to look as if humour could be a hidden theme within the Exodus Narrative. 
'bring your livestock and whatever you have in the field to safety. Every man and beast that are found in the field and are not brought home, when the hail comes down on them, will die' (Ex. 9:19). This wonder is the 'first among the plagues [sic] to attack human life, which it did on a large scale, causing all those exposed to it to perish' (Lockyer 1961:55). Plants and crops were destroyed, livestock and people died. Because YHWH is being described as the 'Author of what we call the laws of nature', Lockyer (1961:55) is of opinion that 'God is able to restrain them, prescribe their proportion, and appoint the place where they should operate.' ${ }^{\prime 0}$

Pharaoh noticed the severity of the storm and called for Moses and Aaron. This is the first wonder where we are told that Pharaoh repented his deeds (Noegel 1995:534). In verse 27 he made three interesting confessions: Firstly, he confessed that he had sinned and secondly, that he as well as his people were wicked. In Exodus 5:2 he had refused to acknowledge that YHWH even existed. Thirdly, he observed that YHWH was righteous (Davis 1986:127). It is, however, doubtful if Pharaoh meant what he said, as he turned his back on what he had promised... again.

\subsubsection{No water}

We now leap to a new tradition: The Wilderness sojourn. Until now YHWH's signs and wonders had two functions, namely to show Israel and the Pharaoh (including the whole of Egypt) that YHWH alone is God and only He has creational power. Secondly, YHWH used His creational power to set Israel free. The water motif showed how YHWH could transform, or turn His own creation upside down. At a setting called Marah, YHWH showed Israel that He can do the opposite as well, by restoring creation (healing water).

There was water at Marah, but it was bitter and therefore undrinkable (Ex 15:22). Thus, the water had to be healed. Water is a matter of life and death. The sea of Reeds showed it clearly, as life (Israel) and death (Egyptians) were separated. But in the desert Israel faced the danger of dehydrating heat, which could most certainly lead to death if there is no water (Durham 1987:213). At Mara another motif, besides the healing motif, therefore 
merges: YHWH who sustains. At Rephidim (Ex 17:1, 2) the story is the same, YHWH can provide (water) even when all (living) hope is lost.

The sustain motif is a close companion to healing as motif. For both of these motifs (healing-and-sustaining) to become real, Israel has to submit/ surrender completely to YHWH and believe in Him as the one who will care for them in the wilderness (Brueggemann 2008:168). Brueggemann (2008:170) says that 'the wilderness tradition, with YHWH as leader and sustainer, is connected directly [to the] experience of dislocation'. In other words, for the real reader of the narrative, who also lived in a time 'said to be without a viable life support system', the wilderness narrative served as 'a theological reflection' regarding their circumstances, thus giving them hope (Brueggemann 2008:170).

It is, however, not just the fact that YHWH is Israel's sustainer that gives them hope, but also the way in which YHWH enters into their circumstances. YHWH sustained Israel not because of what they did, but because he wanted to, and because he entered into a relationship with them (Fretheim 2011:20-21). Being in a relationship, furthermore means that YHWH communicates with his people which He created, through his agent Moses and is 'leading Moses to help that is already available in the world' (Fretheim 2011:22).

\section{Restored rhythm}

At Marah and Rephidim the purpose of the water-motif was 'to assure the people that Yahweh has both the [creational] power and the compassion to provide drinking water and sustenance to people in desperate situations' (Klopper 2005:255).

Klopper (2005:263) confines the motif in the following way: 'Concealed in the chaos there is cosmos and order; in meaninglessness there is meaning; in exile there is hope and restoration - which is what the motif [of water] is ultimately all about' (Klopper 2005:263). Therefore, for the person in exile (587b.C) the water-motif reminds the reader of YHWH's promise of a new beginning, made possible by the Creator WHO can change circumstances as he is able to change nature; he can clean and purify you from your past as he is able to manipulate water; and he can keep you from diseases when you submit to his ordinances. 
By changing the natural rhythm of creation in Egypt and by restoring it again in the Wilderness sojourn, YHWH invited Israel to live in the hope that He would be their healer and sustainer. They had to accept Him as their only Lord though and live according to His ordinances, for there was a downside and a warning: 'If you listen carefully to the voice of the LoRD your God and do what is right in his eyes, if you pay attention to his commands and keep all his decrees, I will not bring on you any of the diseases I brought on the Egyptians, for I am the LorD, who heals you' (Ex $15: 26)$.

Berge (2008:5) points to some similarities between the event in Exodus 15:22 f. and Exodus 7:18, 21, 24, 'which states that the Egyptians could not drink the water of the Nile'. Thus there is a similarity between the experience of the Israelites at Marah and the experience of the Egyptians and the Nile turning into blood. The difference however is a reversed order: The fresh water of the Nile turned into blood which could cause sickness if you drink it. The bitter water of Marah was made sweet by YHWH, and with it Israel received ordinances which would protect them from the diseases which came upon the Egyptians (Ex 15:26).

\section{Conclusion}

In this paper, water as motif has pointed out that $\mathrm{YHWH}$, with His creational power, has the ability to heal and to sustain. As soon as Israel came through the sea of Reeds into the wilderness, they needed to be healed from their longing to go back to Egypt to serve Pharaoh (Leder 2010:95). They also needed to be healed from their fear of the lack of water and food, as YHWH 'alone is their provider and healer' (Burden 1994:47).

Fretheim (1991a:396) mentions that water as motif can refer to chaos (before creation) and that the opposite thereof is dry ground (after creation). In this sense the water motif points towards YHWH's creational power. Creation (life) comes forth out of the chaos and YHWH 'is Lord of Creation' (Lemmelijn 2007:409). Israel bore testimony of how YHWH 'wrought the impossible [...] by a combination of the wonderful and the ordinary [...]' (Childs 2004:238), as all YHWH's marvellous acts has pointed out. 
For the person in exile, the water-motif reminds the reader of YHWH's promise of a new beginning, made possible by the Creator WHO can change circumstances as he is able to change nature; he can clean and purify you from your past as he is able to manipulate water; and he can keep you from diseases when you submit to his ordinances. A new beginning means a new life, away from Egypt and oppression. The contrast between life and death (death/resurrection) is visible in almost every pericope where the water motif is used:

Ex. 1:22: Hebrew babies to be killed in the Nile

Ex. 2:3: Moses was saved in the Nile

Ex. 7:15: Moses must meet Pharaoh at the (life-giving $)^{11}$ water [(mayim)]

Ex. 7:18: Life-giving water of the Nile is transformed into a channel of death (the fish died and the water was undrinkable).

Ex. 8:6: Frogs came from the waters of Egypt and covered the land.

Ex. 8:13, 14: Frogs died instantaneously and the land stank.

Ex. 9:22

Ex. 9:19: Moses warns that hail (water transformed into ice) will destroy all life that does not seek shelter under roof.

Ex. 9:25: Hail struck 'everything in the fields-both men and animals; it beat down everything growing in the fields and stripped every tree.'

Ex. 14:16: Water of the sea of Reeds was divided so that the Hebrews could walk through the sea on dry ground and live.

Ex. 14:27: Water of the sea of Reeds flowed back and the Egyptians and their horses perished.

Ex. 17:3: People cried out because there was no water and they feared death because of the lack of water.

Ex. 17:6: Moses struck a rock and water came out for the people to drink.

11 See TWOT 1188: YHWH is creator and owner of life-giving water. 
By observing, reflecting (thinking), and experiencing what $\mathrm{YHWH}$ had done through 'oth' and 'mophet' in the Wonders, Israel got to know YHWH as their Lord and Deliverer (Ex 14:31).

This is what 'oth' does, it points to events, helping Israel to observe, reflect and experience; it generates awe and admiration; it establishes faith. However, it was not their faith which saved them, as there were many times (as shown by their murmurings) in which they struggled to believe. Israel had to learn that being without life-giving water, is just as dangerous as being without YHWH, thus a life threatening situation.

This lesson was meant to comfort those living in exile (587 BC). But surely, this is a lesson that should also comfort those who feel dislocated from YHWH even during this given time. YHWH is still creator God who has the ability to transform, heal and sustain.

\section{Biblography}

Berge, K 2008. Didacticism in Exodus? Elements of Didactic Genre in

Exodus 1-15. Scandinavian Journal of the Old Testament 22(1):3-28.

BibleWorks 8 electronic edition. Copyright 1992-2008 BibleWorks, LLC.

BibleWorks was programmed by Bushell, MS, Tan, MD \& Weaver, GL.

Birch, BC, Brueggemann, W, Fretheim, TE, Petersen, DL. 1999. A

Theological Introduction to the Old Testament. Nashville: Abingdon Press.

Brueggemann, W 1997. Theology of the Old Testament. Minneapolis:

Fortress Press.

Brueggemann, W 2008. Old Testament Theology. An Introduction. USA:

Abingdon Press.

Burden, TL 1994. The Kerygma of the Wilderness Traditions in the Hebrew Bible. USA: Peter Lang.

Childs, BS 1965. The birth of Moses. Journal of Biblical Literature 84(2):109-122.

Childs, BS 1974b. The Book of Exodus. A Critical, Theological

Commentary. Philadelphia: Westminster Press. 
Childs, BS 2004. The Book of Exodus. USA: Westminster John Knox Press.

Crites, S 1971. The Narrative Quality of Experience. Journal of the American Academy of Religion 39(3):291-311.

Davis, JD 1986. Moses and the Gods of Egypt. Studies in Exodus. Michigan: Baker Book House.

Durham, J 1987. Exodus. World Biblical Commentary. Volume 3. Texas: Word Books Publisher.

Ford, WA 2006. God, Pharaoh, and Moses. Explaining the Lord's Actions in the Exodus Plagues Narrative. Great Britain: Paternoster Biblical Monographs.

Fretheim, TE 1991a. The Plagues as Ecological Signs of Historical Disasters. Journal of Biblical Literature 110(3):385-396.

Fretheim, TE 1991b. Exodus. USA: John Knox Press.

Fretheim, TE 2011. Leading from the Wilderness. International Congregational Journal 10(1):15-28.

Gross, M 2010. Significant Anonymity in Exodus 2. JBQ 38:115-118.

House, PR 1998. Old Testament Theology. USA: Intervarsity Press.

Houtman, C 1988. Exodus I. EenpraktischeBijbelverklaring.Kampen: JH Kok.

Houtman, C 1989. Commentaar van het Oude Testament.Exodus. Deel II. Kampen: JH Kok.

Kaiser, WC Jr. 1990. EXODUS. In Gaebelein, AC (Ed.). The Expositor's Bible Commentary. (Volume 2). USA: Zondervan Publishing House.

Klopper, F 2005. Aspects of creation: The Water in the Wilderness motif in the Psalms and the Prophets. OTE 18(2):253-264.

Leder, AC 2010. Waiting for the land. The Story Line of the Pentateuch. USA: P \& R Publishing.

Lemmelijn, B 2007. Not Fact, yet true Historicity versus Theology in the 'Plague Narrative'. Exodus 7-11. OTE 20(2):395-417. 
Lerner, BD 2010. Crying Out About Frogs. Vetus Testamentum 60:662663.

Lockyer, H 1961. All the Miracles of the Bible. Grand Rapids, Michigan: Zondervan.

Noegel, SB 1995. The Significance of the Seventh Plague. Biblica 76(4):532539.

Propp, WHC 1998. Exodus 1-18. A New Translation with Introduction and Commentary.The Anchor Bible. Volume 2. USA: Doubleday.

Strong, J 2001. The New Strong's expanded Dictionary of Bible Words. USA: Thomas Nelson Publishers.

The Holy Bible: New International Version. 1996, c1984. Grand Rapids: Zondervan.

Tolmie, DF 1999. Narratology and Biblical Narratives. A Practical Guide. Bethesda: International Scholars Publications.

TWOT - The Theological Wordbook of the Old Testament. Harris, L, Archer, GL Jr., Waltke, BK. Chicago, Illinois: Moody Press. (Electronic edition. Copyright (C) 1980).

Ulmer, R 2009. Egyptian Cultural Icons in Midrash. Berlin: Walter de Gruyter $\mathrm{GmbH} \& \mathrm{Co}$.

Van der Walt, JS 2014. A Biblical-theological Investigation of the Phenomenon of Wonders Surrounding Moses, Elijah and Jesus. PhD dissertation: University of the Free State.

Waltke, BC 2007. An Old Testament Theology. USA: Zondervan.

Wilkinson, RH 2003. The Complete Gods and Goddesses of Ancient Egypt. United Kingdom: Thames \& Hudson. 